\title{
Implementing the Flipped Classroom in Elementary and Secondary Schools in China
}

\author{
Jianying Yang \\ School of Foreign Languages \\ China West Normal University \\ Nanchong, P. R. China \\ e-mail: yangjianying23423@163.com
}

\begin{abstract}
In order to analyze the applicability of the flipped classroom in elementary and secondary schools in China, the present situation of the teaching model and the suggestions are discussed. Modern technology makes it possible to implement the flipped classroom in Chinese schools. Successful cases and findings show that Chinese students' learner autonomy and cooperative learning are fostered in this model, and that parents' sense of responsibility in parent involvement in school work is enhanced. It is also argued that there are existing problems in the practice of the flipped classroom, namely, lack of technology, poor performance in the flipped learning video, poor performance in classroom design, and poor monitoring of students' work at home. Based on these problems, it is suggested that more investment from the Chinese government be drawn to schools in the poor and remote areas, that teachers be trained to use modern technology skillfully and design the flipped classroom excellently, and that parents be educated about the teaching model so as to be involved in school education more effectively.
\end{abstract}

Keywords-flipped classroom; learner autonomy; cooperative learning; parent involvement

\section{INTRODUCTION}

The fast development of modern technology makes it possible to practice educational reforms. The flipped classroom, which has become more and more popular among the U.S. educators, is employed by virtue of modern educational technology. Since the two American teachers Jonathan Bergmann and Aaron Sams Pioneered the flipped classroom concept, many teachers around the United States have already implemented flipped classroom strategies. They record their lessons in their computers, create videos of their teaching, or use video lessons from internet sites such as TED-Ed. They flip their classroom by using these available materials as their students' homework. While in class, hands-on activities are implemented through which students do the real inquiry-based learning and active learning. Many cases reported that the flipped classroom has been greatly effective [1][2][3][4][5]. The flipped classroom strategies enhanced active learning in that student academic performance is improved and student engagement and critical thinking is increased. In 2014 NMC Horizon Report, the flipped classroom is regarded as one of the six important developments in educational technology for higher education [6]. With the development of modern technology and the spreading of the flipped classroom initiated by American practitioners, Chinese educators in elementary and secondary education began implementing the flipped classroom recently.

\section{The Present Situation of the Flipped Classroom in ELEMENTARY AND SECONDARY SCHOOLS IN CHINA}

\section{A. The Use of Modern Technology in Education}

The Chinese government also attaches much importance to the use of modern technology in education. Actually in 2010, the Chinese government advocated that information technology shall be put into intensive use and that students shall be encouraged to make use of information technology as a mean for study and become more capable of analyzing and solving problems [7]. It is urged that the application of information technology shall be popularized among the entire population at a higher speed. The development of education informatization will be enhanced within ten years so that the education informatization system will cover all types of schools in urban and suburban areas and the ubiquity of the excellent education resources will be accelerated [8]. The 2014 NPC conference emphasized that more educational resources should be allocated to the central and western regions and rural areas [9]. Based on the advantageous support and the fast development of modern technology, Chinese schools are developing rapidly in innovating the modern technology appliances. The computer and other kinds of electronic appliances are commonly used in classroom so that the students can enjoy their lesson with the help of interesting texts, pictures, and videos that enhance learning.

\section{B. The Successful Implementation of the Flipped Classroom}

In this situation, more and more students can study with the help of different kinds of electronic appliances at school or at home. In urban areas it is convenient for children to have access to the internet when they do their previewing and reviewing of their lessons; it is also convenient for more and more students to use their smart mobile phones and other learning machines to learn new things with the connection of the internet.

Some Chinese educators have also been implementing the flipped classroom with the help of educational technology, as 
in Chongqing Jukui Middle School, Shenzhen Nanshan Experimental School, and Jiulong Middle School of Nanjing.

1) Chongqing JuKui Middle School: Chongqing Jukui Middle School started its flipped classroom in 2011. It is among the first to implement the flipped model in China. In each experiment class, each student is equipped with a tablet which is used for them to download teachers' teaching materials from a certain server. It is surveyed that the majority of the students approve of this teaching model for the reason that it helps to understand important points in lessons [10]. Now it has built up its cloud education platform and other platforms for its students.

\section{2) Shenzhen Nanshan Experimental School: In Shenzhen} Nanshan Experimental School, teachers practice the flipped classroom in different subjects, such us Chinese, mathematics, Geography, and so forth. Micro videos were recorded and put on the internet for students to study before class. At the same time, the school educate the parents about the teaching model to win their support and cooperation. It is now working hard on individualized tutorial, study burden control, and maintenance of subject individuality.

Jiulong Middle School of Nanjing: Jiulong Middle School of Nanjing is trying different new things in its flipped classroom by using micro lessons, whiteboard, and electronic schoolbag. It uses its Autonomous Learning Problem Solving model in courses such as physics and has achieved a great deal.

More and more other elementary and secondary schools are now studying and trying this new model. Teachers assign their students to watch lesson videos and PPT courseware as homework, while they organize classroom discussions and problem-solving activities in class. This flipped model is liked by many practitioners and is now being studied by more and more followers.

Some teachers in colleges and universities are also doing research into and trying the flipped model[11][12][13][14].

\section{The Great Changes the Flipped Classroom May Bring to Chinese Elementary and Secondary Education}

The flipped classroom is a teaching model which inverts the classroom; it is also an educational idea which facilitates learner autonomy, encourages cooperative learning, and presents the parents with more educational responsibilities.

1) Learner autonomy: In traditional teaching, teachers show and explain the teaching content in class; while students sit and listen and absorb what teachers teach. In the flipped model, the teaching content is assigned to students whose job is to learn the content at home before they go to class and talk about and comment on what they have learned at home. This makes it possible for students to study in sufficient time. For example, if students cannot understand a certain part of the recording of a lesson, they can go back and replay that part again and again until they finally understand it. During this process, students can feel free to use a dictionary or other reference books, or to surf the internet for help. This helps students to take the initiative to study, instead of learning things passively in class, as what they might do in traditional classroom. The successful cases indeed show that students become active and interested in studying what their teachers prepare for them. This kind of active learning promotes effective learning.

In the present educational system, Chinese students tend to be passive in learning things in class. The flipped model can be a revolutionary reform in changing Chinese students' passive way of learning things and in training their learner autonomy. The above successful cases of the flipped classroom are good proof that Chinese students' motivation can be activated and their learner autonomy can be fostered.

2) Cooperative learning: Cooperative learning is a method by which a group of learners with the similar goals put all their efforts together under certain stimulation, in order to maximize their own and group learning proficiency. It emphasizes positive interdependence, considerable face-to-face promotive interaction, individual and group accountability, frequent use of the relevant interpersonal and small-group skills, and frequent and regular group processing of current functioning to improve the group's future effectiveness [15]. Findings show that Chinese students are not good at cooperative learning; instead, they are good at visual learning and individual learning, which are mainly rote learning [16][17][18]. This is because the traditional Chinese classroom is the teacher-centered classroom in which teachers spend most of the class time explaining knowledge and while students are just sitting and absorbing it. The flipped model can completely change this situation. Since what teachers should explain in traditional classroom is studied by students before class, this makes it possible for teachers to create more hands-on activities in class to stimulate students. In this situation, organizing different kinds of activities by grouping students becomes a very important and meaningful way to inspire students. By giving different tasks to different members of the students groups, teachers can facilitate students' team work and problem-solving abilities. In this sense, the flipped model provide large spaces for students to practice their team spirits as well as their individual abilities that are crucial for their mental development and hence the bright future of Chinese education.

3) Parental responsibility for education: It is not school's only responsibility to educate a man; instead, family and society contributes a great deal in the growth of a man. According to the Soviet Union educator Suhomlinski, family education plays a first and foremost important role in children's growth. Therefore, parents are responsible for educating children. During the kindergarten years and elementary school years parents can play a very important part by involving themselves in children's homework and in school activities. Studies show that parents' behaviour, parents expectations, parental involvement through time spent on homework have positive effects on students' academic achievement [19][20].

The clipped model calls for more of parents' involvement in children's learning of teachers' assignments about the PPT courseware and different kinds of materials since it is more challenging than ever for children to do such things at home. Children need the help of their parents when they cannot study completely independently. They need the parents' monitoring, encouraging, and participating when possible. When at young ages, children develop their learner autonomy with parents' and 
teachers' involvement to different degrees. With the flipped model, parents can involve more and can be more helpful than with the traditional teaching model, which makes it more possible to help children's all-round development.

\section{The Existing Problems in Carrying out the Flipped Classroom Model}

Although many educators welcome the flipped model with curiosity and enthusiasm, there are still many problems in carrying out this teaching model. Research shows that the results of the practice of the model are not as satisfactory as is expected because of different reasons [21].

1) Lack of technology: There is a growing ubiquity of multimedia tools and appliances that are used in schools with the development of modern technology. In recent years many schools have been equipped with multimedia appliances and the Internet. It is convenient for all university teachers and students to use modern technology. Modern technology indeed brings great changes to Chinese education. Classroom becomes an interesting place for teachers and students, which enhances students' motivation in learning.

However, the situation for elementary and secondary education is not that satisfactory. Many teachers and students in the poor and remote areas in the middle and the west part of China still have little access to technology. In some schools there are even no computers for teaching in classroom; even though there can be two or three computers in other schools, the computers are poorly equipped. In this situation, teachers cannot provide interesting PPT courseware or use any other multimedia resources in class, let alone assign such learning materials to students for their learning at home since students do not have access to technology at all. In the meanwhile, many families in the undeveloped areas do not have a computer at home, which makes it impossible for the flipped model to be practiced.

2) Poor performance in the flipped learning video: During the present teaching practice of the flipped model, poor performance in the flipped learning video poses problems, too. For one thing, some equipment of poor equality may not produce good visual and audio effects for student audiences; this may decrease students' interest and lower the efficiency of their learning. For another, some teachers are not skilled in graphic design, audio editing, compositing and some animation, so that their recordings of their teaching are not appealing to their students.

3) Poor classroom design: In traditional classroom, teachers deliver a great deal of knowledge based on the textbooks and PPT courseware when at the same time students sit, listen, take notes, and absorb things. The traditional model always makes teachers busy in class since they think they have a lot of things to pour into students' mind. The flipped classroom, however, poses a great challenge to teachers who have been used to explaining things all the time in traditional class. Some teachers cannot find new things to do with their students since the teaching materials have been studied by students ahead of time; simply answering students' questions seems monotonous to both teachers and students. Therefore, the poorly-designed classroom creates a new problem in the midst of the teaching reform on the way to the practice of the flipped teaching.

4) Poor monitoring of students' work at home: A growing number of studies have been conducted showing the importance of parent involvement in schools and its relationship to students' achievement. If parents are actively involved in children's education and monitor children's school work and daily activities, children may have higher grades and test scores, and are likely to enroll in higher-level programs and graduate from high school and go on to post-secondary education [22][23]. During the recent two decades, familyschool communication have become closer than ever in China; parents have also realized the responsibility of involving in students' school work. But some schools with the flipped model did not communicate well with parents by educating them about the new model so that parents do not monitor students much; therefore, it is hard to assess students' work at home. The fundamental problem lies in that students' studying of teacher's recordings and materials does not necessarily have anything to do with paperwork; this makes it hard for parents to check students' work and for teachers to assess how well students have done.

\section{Possible Suggestions for and Solutions to the PRACTICE OF THE FLIPPED CLASSROOM}

The flipped classroom has achieved a lot and has been a great success; therefore, to implement this model should be a next step in Chinese educational reform, especially in elementary schools and secondary schools. What should be considered nowadays is to solve the problems that may hinder the model from continuing to be practiced smoothly.

To begin with, more investment should be drawn to the middle and western part of China, especially the remote rural areas. This is also a means to enhance educational excellence, equity and efficiency.

Secondly, teachers should be trained in using high-tech facilities, mastering skills to produce excellent recordings, designing perfect pre- and post- class teaching plans to enhance students' active learning and effective learning, and take actions to cultivate instructional partnerships with parents.

Thirdly, parents should be educated to be involved in school work by monitoring student's school work and daily activities, communicating frequently with teachers, and helping develop their plans for education or work after school.

The above suggestions and solutions can help to promote learner autonomy, cooperative learning, and creative thinking. It is hoped that the flipped classroom model can be used by more and more teachers and can benefit more and more students and hence it can benefit Chinese education. 


\section{CONCLUSION}

The flipped classroom is still new in China, but it is developing fast. Modern technology and parent-teacher communication facilitates its implementation; most importantly, teachers are a great force to push this teaching reform. There are still some barriers that hinder the flipped strategies; however, the flipped classroom has become a concept in teaching. The purpose of this kind of educational reform is to explore students' learning and improve teaching efficiency. To raise learner autonomy and inquiry-based learning is the key goal of the model.

\section{ACKNOWLEDGMENT}

This research is supported by a grant from Sichuan Centre for Education Development Research (No. CJF011010). The author acknowledges Dr. Gao Chang for his invaluable data and useful suggestions.

\section{REFERENCES}

[1] C. Papadapoulos, \& A. S. Roman, "Implementing an inverted classroom model in engineering statistics: Initial results," Proceedings of the 40th ASEE/IEEE Frontiers in Education Conference ,Washington, DC, October 2010

[2] K. Fulton, "Inside the flipped classroom," The Journal, Retrieved from http://thejournal.com/ articles/2012/04/11/the-flipped-classroom.aspx, April 2012.

[3] J. Bergmann, and A. Sams, Flip Your Classroom: Reach Every Student in Every Class Every Day. Eugene, OR: International Society for Technology in Education, 2012.

[4] G. Green, "The flipped classroom and school approach: Clintondale High School," Presented at the annual Building Learning Communities Education Conference, Boston, MA. Retrieved from http://2012.blcconference.com/documents/flipped-classroom-schoolapproach.pdf, July 2012.

[5] N. Warter-Perez and J. Dong, "Flipping the classroom: How to embed inquiry and design projects into a digital engineering lecture," Proceedings of the 2012 ASEE PSW Section Conference, San Luis Obispo, April 2012.

[6] National Media Consortium. NMC Horizon Report: 2014 Higher Education Edition, 2014.

[7] Outline of China's National Plan for Medium and Long-Term Education Reform and Development (2010-2020). Beijing: People's Publishing House, 2010.

[8] Ten-year plan for the Development of Education Informatization (20112020). Retrieved from http://www.moe.gov.cn/publicfiles/business/htmlfiles/moe/s3342/20120 3/133322.html, March 2012.
[9] Report on the Work of the Government. Retrieved from http://news.sohu.com/20140305/n396079298.shtml, March 2014.

[10] H. Wang, W. Zhao, L. H. Sun, and H. X. Liu, "The design of flipped classroom teaching model: Analysis based on typical cases at home and abroad," Modern Educational Technology, vol. 23, Aug. 2013, pp. 5-10.

[11] X. D. Wang, and C. J. Zhang, "The application research of flipped classroom in university teaching: A case study on professional English of educational technology," Modern Educational Technology, vol. 23, Aug. 2013, pp. 11-16.

[12] Z. Liu and Z. X. Cao, "The practice and thinking of the flipped classroom model in the ideological and political education," Modern Educational Technology, vol. 23, Aug. 2013, pp. 17-20.

[13] X. L. Ma, G. Q. Zhao, and T. Wu. "An empirical study on the influence of flipped classroom model on information technology course teaching," Journal of Distance Education, Jan. 2013, pp. 79-85.

[14] X. P. Chen, "The miracle of inverting the traditional educational model: The practice of the flipped classroom in business English writing in adult education," China Adult Education, Oct. 2013, pp. 122-124.

[15] Q. Lu, "Reflections of the flipped classroom: An empirical study," EEducation Research, Aug. 2013, pp. 91-97.

[16] D. Johnson, R. Johnson, and E. Holubec, Advanced Cooperative Learning. Edin, MN: Interaction Book Company, 1988.

[17] C. D. Melton, "Bridging the cultural gap: A study of Chinese students' learning style preferences," RELC Journal: A Journal of Language Teaching and Learning in Southeast Asia, vol. 21, Jun. 1990, pp. 29-54, doi: $10.1177 / 003368829002100103$.

[18] Sit, H. H. W. "Characteristics of Chinese students' learning styles," International Proceedings of Economics Development \& Research, Aug. 2013, pp. 36-39.

[19] P. G. Fehrmann, T. Z. Keith, and T. M. Reimers, "Home influence on school learning: Direct and indirect effects of parental involvement on high school grades," The Journal of Educational Research, vol. 80, 1987, pp. 330-337.

[20] M. M. Englund, A. E. Luckner, G. J. Whaley, and B. Egeland, "Children's achievement in early elementary school: Longitudinal effects of parental database: PsycARTICLES involvement, expectations, and quality of assistance," Journal of Educational Psychology, vol. 96, 2004, pp. 723-730.

[21] Q. Lu, "Reflections of the flipped classroom: An empirical study," EEducation Research, Aug. 2013, pp. 91-97.

[22] A. T. Henderson, and N. Berla, A New Generation of Evidence: The Family is Critical to Student Achievement. Washington, DC: National Committee for Citizens in Education, 1994.

[23] A. T. Henderson, and K. L. Mapp, A New Wave of Evidence: The Impact of School, Family, and Community Connections on Student Achievement: Annual Synthesis 2002. Austin, TX: National Center for Family \& Community Connections with Schools, 2002. 